\title{
Oceanography
}

CITATION

Edinger, E. 2012. Gold mining and submarine tailings disposal: Review and case study.

Oceanography 25(2):184-199, http://dx.doi.org/10.5670/oceanog.2012.54.

DOI

http://dx.doi.org/10.5670/oceanog.2012.54

COPYRIGHT

This article has been published in Oceanography, Volume 25, Number 2, a quarterly journal of The Oceanography Society. Copyright 2012 by The Oceanography Society. All rights reserved.

USAGE

Permission is granted to copy this article for use in teaching and research. Republication, systematic reproduction, or collective redistribution of any portion of this article by photocopy machine, reposting, or other means is permitted only with the approval of The Oceanography Society. Send all correspondence to: info@tos.org or The Oceanography Society, PO Box 1931, Rockville, MD 20849-1931, USA. 


\section{Gold Mining and \\ Submarine Tailings Disposal \\ Review and Case Study}

BY EVAN EDINGER

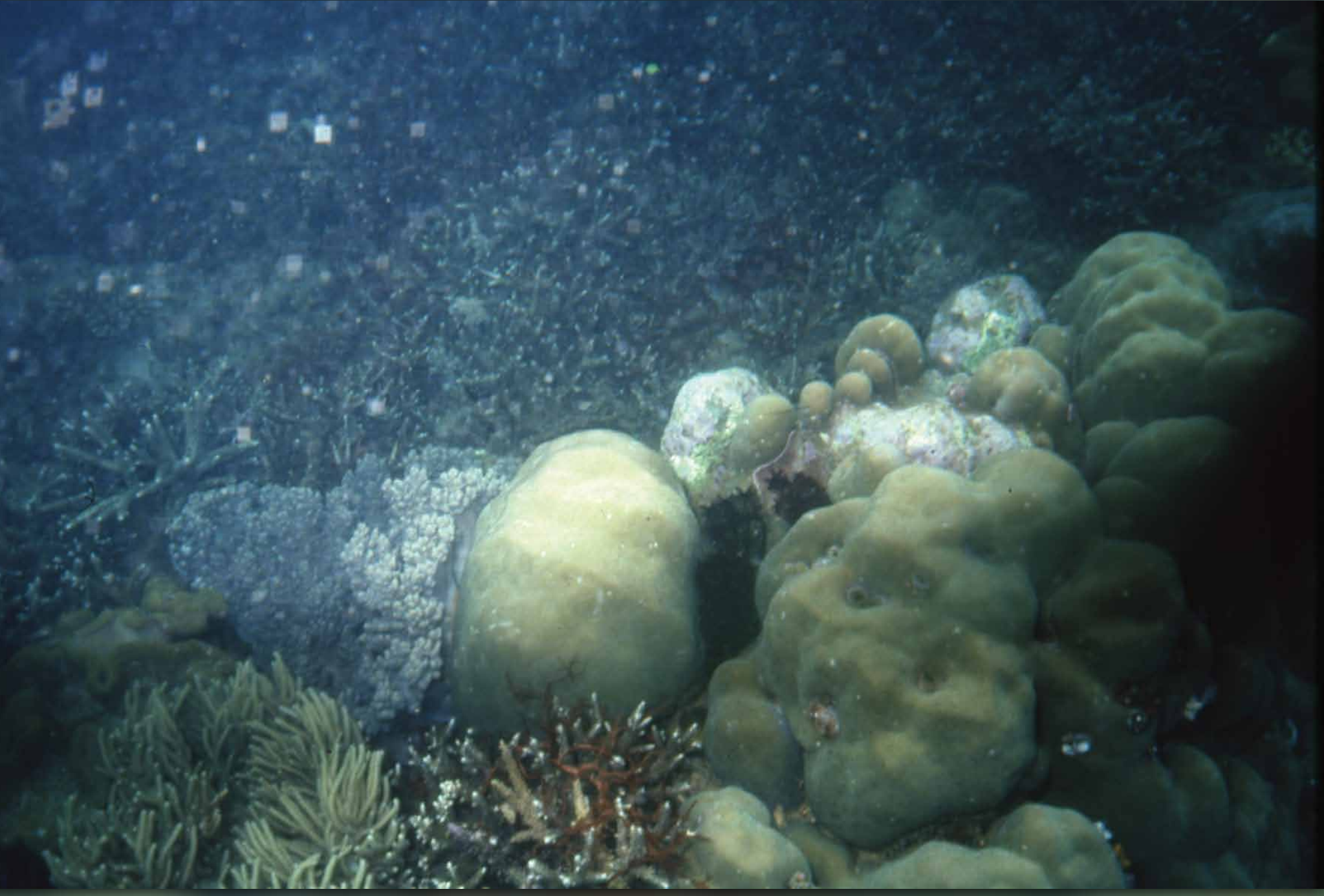

A fringing coral reef in Buyat Bay, Indonesia, June 2002. This reef at $3 \mathrm{~m}$ depth is closest to gold mine tailings outfall. Note high water turbidity, and the mixture of live and dead corals. 
ABSTRACT. Environmental impacts associated with submarine tailings disposal (STD) of gold mine wastes vary widely among the relatively few cases studied. The principal contaminants of concern surrounding most gold mines are arsenic, mercury, and cyanide, although antimony, thallium, lead, zinc, and copper may also be important in particular mines. The mineralogy and ore processing techniques associated with different kinds of gold deposits may strongly influence the outcome of STD. Native gold and its associated minerals are generally less toxic than sulfidemineral gold, in which the gold is incorporated into sulfide minerals in conjunction with other trace elements. Sulfide gold tailings placed in seawater may be particularly dangerous where ore processing includes oxidation by roasting or aggressive chemical leaching, which transforms the sulfide minerals into relatively unstable oxides and oxy-hydroxides.

The case study of the Newmont Minahasa Raya gold mine in Indonesia highlights some of the dangers of gold mine STD. Local villagers observed fish kills shortly after the beginning of STD operations, and they also noted fine red sediment resembling the tailings smothering corals on reefs adjacent to the tailings disposal site. Tailings from this mine dispersed from the intended STD depth of $82 \mathrm{~m}$ up to nearby coral reefs, and dispersal extended up to $3.5 \mathrm{~km}$ from the end of pipe. Unstable arsenic phases in the tailings accounted for at least $32 \%$ of total arsenic in the mine tailings, and less than $10 \%$ of total arsenic in fluvially derived marine sediments. Mercury in the submarine tailings was methylated in approximately the same proportions as mercury from artisanal gold mines using mercury amalgamation and in uncontaminated nearshore marine sediments near a watershed with similar bedrock geology. Methyl mercury derived from tailings was incorporated into the local food chain, probably via benthic invertebrates.

\section{INTRODUCTION}

Gold has tremendous cultural and economic importance around the world, and gold mining is one of the oldest forms of mining on the planet. Even the Romans noted environmental issues associated with gold mining, particularly from mercury release related to gold ore processing (de Lacerda and Salomons, 1998). The environmental legacy of historical gold mining includes mercury and arsenic contamination of soil, surface water, and groundwater; massive soil erosion; and river degradation associated with placer mining (e.g., Eisler, 2004a). The twentieth-century invention of cyanidation for gold extraction minimized industrial use of mercury for gold extraction, but small-scale gold mining using mercury amalgamation resurged in the 1970s, causing a new wave of mercury contamination resulting from gold mining (de Lacerda and Salomons, 1998).

Submarine tailings disposal (STD), the intentional dumping of mine tailings in the ocean, is a relatively new technique for tailings management, and has rarely been applied to gold mines. A few geologists have advocated subaqueous (in lakes) or submarine tailings disposal as a method to avoid acid mine drainage (AMD) associated with massive sulfide deposits, mostly of base metals such as iron, nickel, copper, and zinc (Pedersen, 2001). AMD results from the oxidation of metal sulfides in mine wastes (or water flow through mine workings) by atmospheric oxygen, releasing sulfuric acid, which then promotes further dissolution of sulfide minerals and toxic metal release, in a positive feedback loop leading to very low $\mathrm{pH}$ and very high metal concentrations in solution (Jambor, 2003). Sulfide tailings are stored underwater in tailings ponds to reduce oxygen availability, hence, to avoid AMD. The mining industry often proposes STD as the best solution for tailings management for coastal areas with high seismic activity or rainfall vastly exceeding evaporation, two conditions that potentially threaten the stability of terrestrial tailings pond dams (Ellis et al., 1995). Submarine and subaqueous tailings disposal are both considerably less costly than standard tailings disposal in an artificial structure (Mudd and Boger, in press). An important difference between submarine and subaqueous tailings disposal is that lakes typically have weaker wave and current action than coastal marine settings, and lake sediments experience less bioturbation than marine sediments (Renaut and Gierlowski-Kordesch, 2010).

Where STD has been applied to gold mine tailings (Figure 1), the environmental impacts have been highly variable (Table 1, see case study below, Shimmield et al., 2010, and Rotmann and Thomas, in press). STD has been considered for a number of other gold mines, and pilot studies on tailings toxicity have been carried out, but STD has
Evan Edinger (eedinger@mun.ca)
is Associate Professor, Departments of Geography, Biology, and Earth Sciences, Memorial University, St. John's, Newfoundland and Labrador, Canada. 


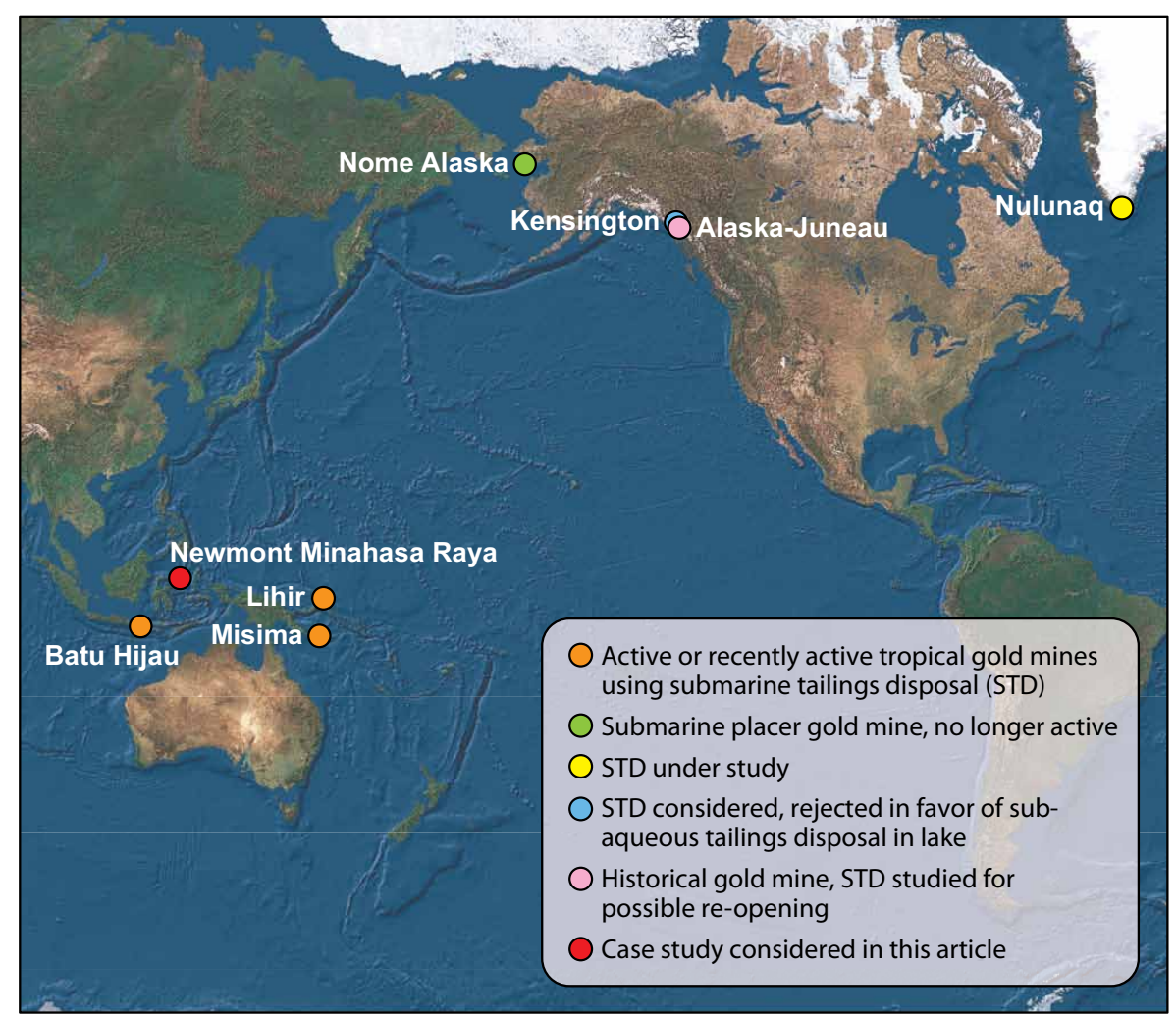

Figure 1. Map showing locations of active, recent past, and proposed gold mines using submarine tailings disposal (STD), and mines that have considered STD, with data published in the scientific literature. See Reichelt-Brushett, in press, for map of additional sites in the coral triangle region.

not (yet) been implemented at these mines (Table 2, Figure 1; see ReicheltBrushett, in press, for a more extensive list, including sites outside published scientific literature).

\section{GOLD ORE TYPES AND MINERALOGIES, DEPOSIT TYPES, AND PROCESSING TECHNIQUES}

Gold commonly occurs naturally as native (metallic) gold. In lode gold deposits, native gold occurs in association with quartz, carbonate minerals, and sulfide minerals hosted in veins or other morphologies, and in igneous or metamorphic rocks. Native gold is also concentrated in placer deposits resulting from surficial erosion and hydraulic
Nova Scotia, Canada (Jamieson, 2011), and there are many European examples (reviewed in Magalhães, 2002).

Not all native gold deposits are rich in arsenic and mercury. Porphyry copper-gold deposits, such as the Batu Hijau deposit in Sumbawa, Indonesia (Gwyther et al., 2009), or Bougainville, Papua New Guinea, contain almost no arsenic. In these cases, copper is often the main source of toxicity, particularly to molluscs, and the sedimentation is the principal threat to epifauna (Jeffery, 1988).

Because native gold is not chemically bound as a solid solution in associated sulfide minerals, larger particles of native gold can be extracted by mechanical means, such as crushing and milling of lode deposits or hydraulic sorting of placer deposits (gold pans, sluice boxes, and other traditional mining techniques). Smaller particles of native gold are extracted by mercury amalgamation, a very old technique, used extensively by the Romans and in medieval Spain (de Lacerda, 2003).

Because mercury and gold have a natural affinity for each other, applying liquid mercury to crushed ore extracts gold from those materials as a mercurydominant alloy (amalgam). Heating then volatilizes the mercury, which is sometimes captured for re-use in retorts or reflux systems. Mercury release from gold mining by mercury amalgamation is a major source of mercury release to the environment, particularly in developing world locations not affected by other industrial sources of mercury such as extensive coal combustion or the chlor-alkali industry (de Lacerda, 2003). Tailings from native gold deposits treated with mercury amalgamation leave 
considerable mercury residues. Mercury contamination from historical mining activities has caused high levels of soil mercury contamination in Australia, California, and elsewhere (de Lacerda and Salomons, 1998; Churchill et al., 2004; Alpers et al., 2005).

In some gold deposits, gold occurs wholly or partially as a chemically bound solid solution constituent of pyrite $\left(\mathrm{FeS}_{2}\right)$, arsenian pyrite, or arsenopyrite (FeAsS). In some sediment-hosted disseminated gold deposits, pyrite or arsenopyrite (and sometimes additional sulfide minerals, including orpiment
$\left[\mathrm{As}_{2} \mathrm{~S}_{3}\right]$, realgar $\left[\mathrm{As}_{4} \mathrm{~S}_{4}\right]$, stibnite $\left[\mathrm{Sb}_{2} \mathrm{~S}_{3}\right]$, and cinnabar $[\mathrm{HgS}]$ ) precipitated in sedimentary rocks as a result of hydrothermal fluid migration. They are broadly termed Carlin-type deposits, after the Carlin Trend of northern Nevada, USA. Carlin-type deposits typically have anomalously high occurrences of four toxic elements: arsenic (As), antimony $(\mathrm{Sb})$, thallium ( $\mathrm{Tl})$, and mercury $(\mathrm{Hg})$. Most known Carlin-type deposits are mined in continental settings far from the ocean. However, some are exploited in coastal environments-and one mine exploiting a Carlin-like deposit has used
STD (Newmont Minahasa Raya mine;

Turner et al., 1994; see case study below).

Because arsenic is a metalloid, having properties that are in between those of metals and nonmetals, it reacts differently from other toxic heavy metals during ore processing (Magalhães, 2002). The processing techniques for sulfide ores, which involve oxidation of the ore by roasting or chemical leaching, convert gold-bearing pyrite and arsenopyrite into less environmentally stable minerals, often iron oxides and oxy-hydroxides (e.g., Burns and Burns, 1979; Weeks and Wan, 2000). Although sulfide base metal

Table 1: Gold mines using submarine tailings disposal (STD).

\begin{tabular}{|c|c|c|c|c|}
\hline Mine Name & Country & Deposit Type & $\begin{array}{l}\text { Major } \\
\text { Contaminants of } \\
\text { Concern }\end{array}$ & $\begin{array}{c}\text { Sample References in Primary } \\
\text { Scientific Literature }\end{array}$ \\
\hline $\begin{array}{l}\text { Nome Offshore } \\
\text { Placer Project }\end{array}$ & Alaska, USA & Submarine placer & Sediment & Jewett et al. (1999) \\
\hline Misima & Papua New Guinea & $\begin{array}{c}\text { Epithermal Carbonate } \\
\text { base-metal } \mathrm{Au}-\mathrm{Ag}\end{array}$ & $\mathrm{Pb}, \mathrm{Zn}$ & $\begin{array}{c}\text { Fallon et al. (2002); } \\
\text { Shimmield et al. (2010) }\end{array}$ \\
\hline Lihir & Papua New Guinea & Proximal quartz-sulfide-gold & $\mathrm{Cu}, \mathrm{As}, \mathrm{Cd}, \mathrm{Hg}, \mathrm{Pb}$ & $\begin{array}{c}\text { Brewer et al. (2007); } \\
\text { Shimmield et al. (2010) } \\
\text { Rotmann and Thomas, (in press) }\end{array}$ \\
\hline Batu Hijau & Indonesia & Porphyry copper with gold & $\mathrm{Cu}$ & $\begin{array}{l}\text { Gwyther et al. (2009); } \\
\text { Sahami et al. (2011) }\end{array}$ \\
\hline $\begin{array}{c}\text { Newmont } \\
\text { Minahasa Raya }\end{array}$ & Indonesia & $\begin{array}{l}\text { Sediment-hosted hypothermal } \\
\text { (Carlin-type) }\end{array}$ & $\mathrm{As}, \mathrm{Sb}, \mathrm{Hg}, \mathrm{Tl}$ & $\begin{array}{c}\text { Edinger et al. (2007, 2008); } \\
\text { Blackwood and Edinger (2007); } \\
\text { Lasut et al. (2010) }\end{array}$ \\
\hline
\end{tabular}

Table 2. Gold mines where submarine tailings disposal (STD) was considered and experimental treatments were published in scientific literature. This list focuses on high-latitude sites (see Reichelt-Brushett, in press, for a list of gold mines proposing STD within the coral triangle region).

\begin{tabular}{|c|c|c|c|c|}
\hline \multirow{2}{*}{ Mine Name } & Country & Deposit Type & $\begin{array}{c}\text { Major } \\
\text { Contaminants of } \\
\text { Concern }\end{array}$ & $\begin{array}{c}\text { Sample References in Primary } \\
\text { Scientific Literature }\end{array}$ \\
\hline Kensington & Alaska, USA & Carbonate-hosted gold vein & Pb, Zn & Kline and Stekoll (2001) \\
\hline Alaska-Juneau & Alaska, USA & Carbonate-hosted gold vein & $\mathrm{Pb}, \mathrm{Zn}$ & Johnson et al. (1998a,b) \\
\hline Nalunaq & Greenland & Mesothermal gold vein & $\mathrm{As}, \mathrm{Cu}, \mathrm{Cd}, \mathrm{Cr}$ & Matthies et al. (2011) \\
\hline
\end{tabular}


ores are relatively unreactive in water, due to the dearth of oxygen, arsenic incorporated into metastable iron oxides and oxy-hydroxides, or other metastable minerals, becomes more soluble under reducing conditions. Thus, arsenic incorporated into metastable phases such as Fe-oxy-hydroxides can dissolve into sediment pore water and migrate vertically, returning to the sediment-water interface, where it again precipitates (Martin and Pedersen, 2002). The dissolution and re-precipitation of arsenic in these metastable phases also permits transformations of arsenic between its less-toxic As-V and more toxic As-III chemical forms (e.g., Walker et al., 2009). Inorganic arsenic readily bioaccumulates, but does not generally biomagnify up the marine food chain (Magalhães, 2002). When arsenic is methylated, or otherwise complexed into organoarsenic compounds, it becomes more biologically available and more toxic than its inorganic forms (e.g., Andreae and Klumpp, 1979; Eisler, 2004b).

In theory, STD relies on natural sedimentation to bury mine tailings beneath uncontaminated sediments, thus isolating the tailings from biological activity (Ellis, 2008). This conceptual model of STD depends on rapid sedimentation rates, and it fails to account for sediment failures and slumping (e.g., Burd et al., 2000) or for bioturbation, the ability of deposit-feeding benthic biota to vertically mix sediment. When partially buried tailings on sloping bottoms slump, they may become exposed at the surface again, increasing the potential for their contact with benthic fauna (Burd et al., 2000). Mine tailings are typically low in organic matter and high in toxic metals and metalloids, and should be unattractive to deposit-feeding biota. Bioturbating fauna can mix shelf-depth sediments down to $1 \mathrm{~m}$ depth, and continental slope sediments to a shallower depth. Because of the natural tendency of arsenic to dissolve under reducing conditions below the sediment-water interface, percolate upward, and reprecipitate under more oxidizing conditions, deposit-feeding fauna may be exposed to arsenic-laden sediment pore water, providing a potential pathway for contamination into the food chain (Blackwood and Edinger, 2007). The reducing, acidic gut tracts of many deposit-feeding invertebrates (Ahrens and Lopez, 2001) can transform the mineralogy of clay particles (Needham et al., 2004), supporting the notion that deposit-feeding invertebrates can accelerate the diagenesis of arsenic in submarine mine wastes from more stable to less-stable forms, and transfer arsenic into the food chain. When different fish species living near submarine gold mine tailings in Indonesia were tested, the demersal fish feeding on benthic invertebrates on flat sandy or muddy bottoms typically exhibited the highest arsenic burdens (Shepherd-Miller Inc., 2001).

\section{MERCURY RELEASE}

Although most mercury contamination associated with gold mining comes from past or present mercury amalgamation (e.g., de Lacerda and Salomons, 1998), mercury is present in many gold deposits as an associated trace element. Mercury present as cinnabar (mercuric sulfide, $\mathrm{HgS}$ ) is relatively refractory, like pyrite, but ore processing techniques may transform mercury to more labile forms (Eisler, 2004c). Cyanidation may facilitate $\mathrm{Hg}$ release where residual cyanide remains in tailings (e.g., Shaw et al.,
2006). Once mercury is available at the sediment-water interface as metallic mercury or in metastable phases, it can be methylated by bacterially mediated processes (de Lacerda and Salomons, 1998). Methyl mercury is acutely toxic and readily biomagnifies up marine food webs.

\section{CYANIDE}

Cyanidation has been used since the 1930 s to extract gold from ore in a variety of processes, including heap-leach of crushed ore, or contained cyanide leach of processed ore (Eisler, 2004a). Although cyanide does not generally persist in the environment as do heavy metals and metalloids, it is acutely toxic. Cyanide's toxicity has been an obvious impediment to attempts to provide alternatives to mercury amalgamation in small-scale gold mining. Although cyanide used in treating gold ores is meant to be detoxified by oxidation to cyanate before tailings are discharged, low concentrations of cyanide often persist in gold mine tailings, and may be gradually released to the environment over protracted periods (Shaw et al., 2006). While gold-mining-related cyanide impacts on wildlife in terrestrial settings have been extensively studied (e.g., Eisler 2004a; Donato et al., 2007), the impacts of cyanide residues in submarine tailings are relatively unknown. Residual cyanide toxicity may limit colonization of freshly deposited gold mine tailings on the seabed, but the duration and severity of this impact are unknown.

\section{SEDIMENT QUALITY GUIDELINES}

Sediment quality guidelines have been proposed as effective approaches to preventing chemical and biological impacts 
on marine biological communities (CCME, 2002; Bjørgesæter and Gray, 2008). Canadian Council of Ministers of Environment (CCME) sediment quality guidelines include two concentrations for many contaminants: a recommended sediment quality guideline (SQG), and a probable effects level (PEL). For example, the CCME interim marine sediment quality guideline (IMSQG) for arsenic is $7.5 \mathrm{ppm}$, while the PEL for arsenic in marine sediments is $41 \mathrm{ppm}$. Background arsenic concentrations in uncontaminated marine sediments from gold districts may easily exceed the IMSQG for arsenic. By contrast, the PEL is toxicologically based and indicates a contaminant level at which biological impacts on organisms can be expected, and below which impacts are not predicted. Because the concentration at which a given contaminant has toxicological effects varies among organisms and environments, other authors have suggested that a suitable rule of thumb for sediment quality is for contaminant concentrations not to exceed four times background levels (Bjørgesæter and Gray, 2008). CCME guidelines are based on whole sediment concentrations, but most studies use the silt and clay fraction $(<63 \mu \mathrm{m})$ only, as this standardization avoids most grainsize biases. Grain-size biases are particularly important in mixed carbonatesiliciclastic sediments, in which the coarser biogenic carbonate fraction of the sediment contains far lower trace element concentrations than the finer siliciclastic fraction (David, 2002). Although sediment quality guidelines are used as reference values, they have no legal or regulatory status.

\section{SEDIMENTATION AND \\ TAILINGS DISPERSAL}

Apart from the toxins contained in gold mine tailings, the increased sedimentation rates associated with submarine tailings disposal may have a biological impact on surrounding benthic marine communities. These impacts do not differ in nature from sedimentation associ- ocean involves far greater risks of tailings mobility than subaqueous tailings disposal in lakes or artificial tailings ponds (Pedersen, 2001). Proponents of STD have argued that tailings disposal into deep water $(>150 \mathrm{~m})$ minimizes risks because most human exploitation of marine species is from shallowwater environments such as coral reefs

\section{$\int S_{\text {VERY FEW ENVIRONMENTAL STUDIES OF }}$ INTENTIONAL PLACEMENTS OF GOLD MINE TAILINGS IN THE OCEAN HAVE BEEN PUBLISHED IN THE SCIENTIFIC LITERATURE.}

ated with STD of other types of mine tailings, which have been extensively reviewed elsewhere (e.g., Ellis et al., 1995; Burd et al., 2000; Blanchette et al., 2001; Ellis, 2008).

One of the greatest concerns with STD is dispersal of mine tailings away from their intended disposal site by waves, currents, or sediment mass transport (Burd et al., 2000; Ellis, 2008). Although STD avoids the risks of tailings dam failure, it gives up the ability to control what happens to the tailings after they are released to the ocean. Coastal ocean waters are far more dynamic depositional environments than lakes (Renaut and Gerlowski-Kordesch, 2010), with the potential action of surface waves, internal waves, tidal currents, contour currents, storm-induced scour and currents, and tsunamis. Therefore, submarine tailings disposal in the (e.g., Ellis et al., 1995; Ellis, 2008). This assumption fails to recognize the diversity of deepwater fauna such as corals and fishes, particularly around submarine canyons (e.g., Sink et al., 2006; De Leo et al., 2010), where STD outfalls are frequently placed (e.g., Shimmield et al., 2010). Furthermore, human exploitation of the sea has expanded into deeper waters in many parts of the world, as shallow-water fish stocks become depleted (Pauly et al., 2005).

\section{CASE STUDY |}

STD at the Newmont Minahasa

Raya Gold Mine, Indonesia

Very few environmental studies of intentional placements of gold mine tailings in the ocean have been published in the scientific literature. Published examples include discussions of the Newmont Minahasa Raya (NMR) gold mine 
in North Sulawesi, Indonesia, along with the Lihir and Misima gold mines in Papua New Guinea (Fallon et al., 2002; Brewer et al., 2007; Rotmann and Thomas, in press). Ironically, the NMR mine was intensively studied because of difficulties with the STD system, and because of complaints by the local population, which were acted upon by the Indonesian government and by Indonesian and foreign nongovernmental environmental organizations. The mine used a relatively shallow STD system, with the pipe ending at $82 \mathrm{~m}$ water depth, and it was an unusual deposit type for tropical island settings where STD is often advocated.

The NMR gold mine was a relatively small deposit that was mined from 1996 to 2004 to exploit a sediment-hosted Carlin-like deposit with As-Sb-Hg-Tl anomalies (Turner et al., 1994). Volcanic rocks in the watersheds surrounding the mine hosted native gold deposits that were exploited by small-scale miners using mercury amalgamation. The confusion induced by multiple sources of mercury contamination contributed to the virulence of the controversy surrounding STD at the NMR mine. The STD system for this small mine deposited only 2,000 tonnes per day of tailings, mixed 7:1 with seawater, into waters $82 \mathrm{~m}$ deep, approximately $900 \mathrm{~m}$ from shore. Although this tailings outfall depth was shallower than that of most modern STD operations, which usually have tailings outfalls deeper than $100 \mathrm{~m}$ (Ellis, 2008), and it was on a gentler slope than usually recommended, the STD system for this mine was operated according to its permits from the Indonesian government. The average concentrations of arsenic, antimony, and mercury in the tailings sampled in 2002 and 2004 were 590-690 ppm As, 490-580 ppm Sb, and 0.8-5.8 ppm $\mathrm{Hg}$, about 20-30 times higher than the pre-mining average arsenic concentration in local seafloor sediments (Edinger et al., 2007). These concentrations are consistent with those predicted in the environmental impact assessment (PTNMR, 1994) for the mine and in ore-processing testing procedures (Weeks and Wan, 2000). Shortly after the mine commenced its STD system, local fishermen began to report fish kills and tailings dispersal onto nearby fringing coral reefs. The STD system also suffered a pipe burst in 1998, which released more tailings into waters close to the beach community of Buyat Pantai (Figure 2). The mine was closed at the height of the controversy over the impacts of its STD system, not because of the controversy, but because the ore deposit had been fully exploited. Shortly after the mine closed, three executives from the mining company were arrested and tried on environmental charges related to contamination of the bay. The mining company executives were acquitted, but the company later reached an out-of-court settlement in a civil suit. Most of the villagers of Buyat Pantai were eventually resettled to a different location after the mine closed in 2004, although lack of infrastructure in their new location made the transition difficult (Siregar, 2005).

Environmental consultants hired by the mining company carried out an environmental impact assessment (AMDAL) before the mine opened (PTNMR, 1994), and then a separate environmental risk assessment after the mine opened and local villagers began to complain of

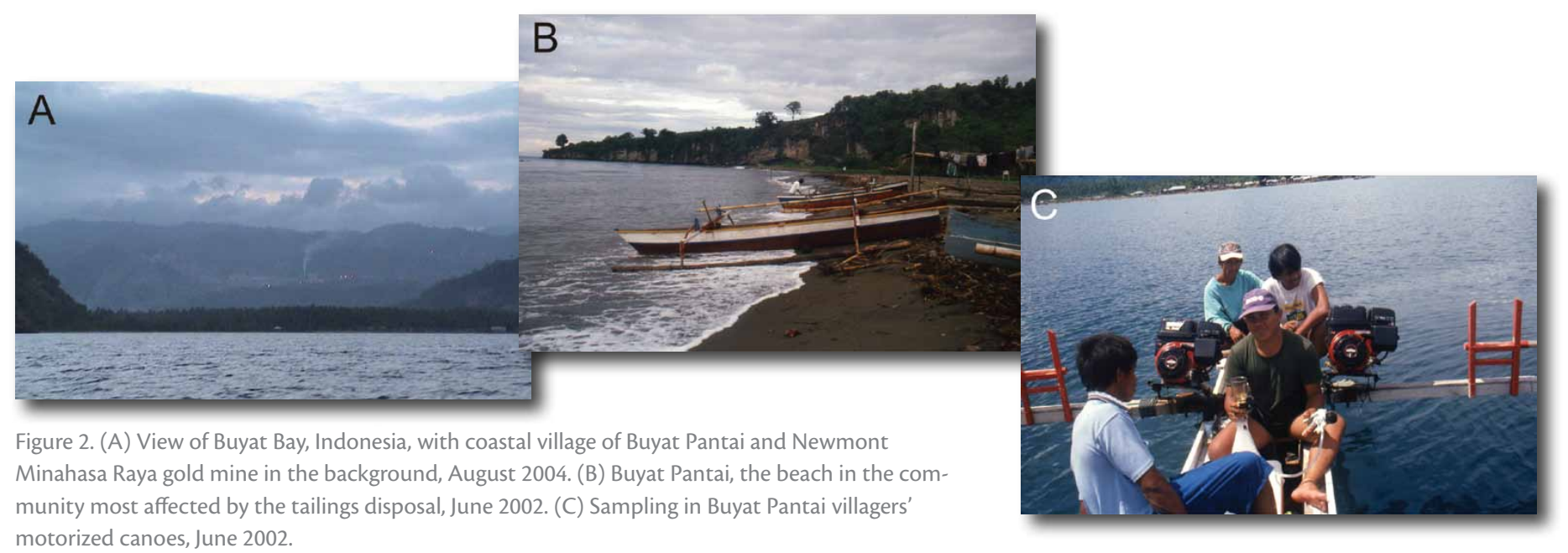


fisheries and health impacts (ShepherdMiller Inc., 2001). Importantly, the AMDAL included the determination of sediment trace element concentrations from a number of locations surrounding the mine, facilitating before-and-after studies. Although a before-after-controlimpact (BACI) study was not possible for this mine, sediment trace element concentrations could be compared for similar locations before and after the STD operations. The environmental risk assessment studied contaminant concentrations in a variety of fish species caught in Buyat Bay (the site of the STD system), an adjacent bay, and open waters offshore (Shepherd-Miller Inc., 2001).

\section{Tailings Dispersal}

Sediment samples collected six and eight years after the beginning of STD operations showed that tailings had dispersed from the intended deposit site at $82 \mathrm{~m}$ depth upward into shallower water throughout Buyat Bay, the small bay in which the tailings were disposed (Figure 3 ). The tailings pile height itself was about $11 \mathrm{~m}$ above the seafloor in December 2000 (PTNMR, 2002a). A seafloor survey determined that the tailings pile occupied an area of $300 \times 600 \mathrm{~m}$ in December 1999

$\left(0.18 \mathrm{~km}^{2}\right)$ and $380 \times 750 \mathrm{~m}$ in December 2000 (0.285 km²; PTNMR 2002a) inside a small submarine valley at the mouth of Buyat Bay, and above a $100 \mathrm{~m}$ deep shelf that extended seaward for approximately $5 \mathrm{~km}$. Mining company surveys identified tailings dispersal up to the $50 \mathrm{~m}$ depth contour, with tailings thicknesses ranging from $20-40 \mathrm{~cm}$ away from the main tailings pile. The mining company attributed these dispersed tailings to a brief period of widespread tailings discharge when the mine first commenced STD operations in March 1996, before the mouth of the outfall pipe became covered in tailings (PTNMR, 2002a).

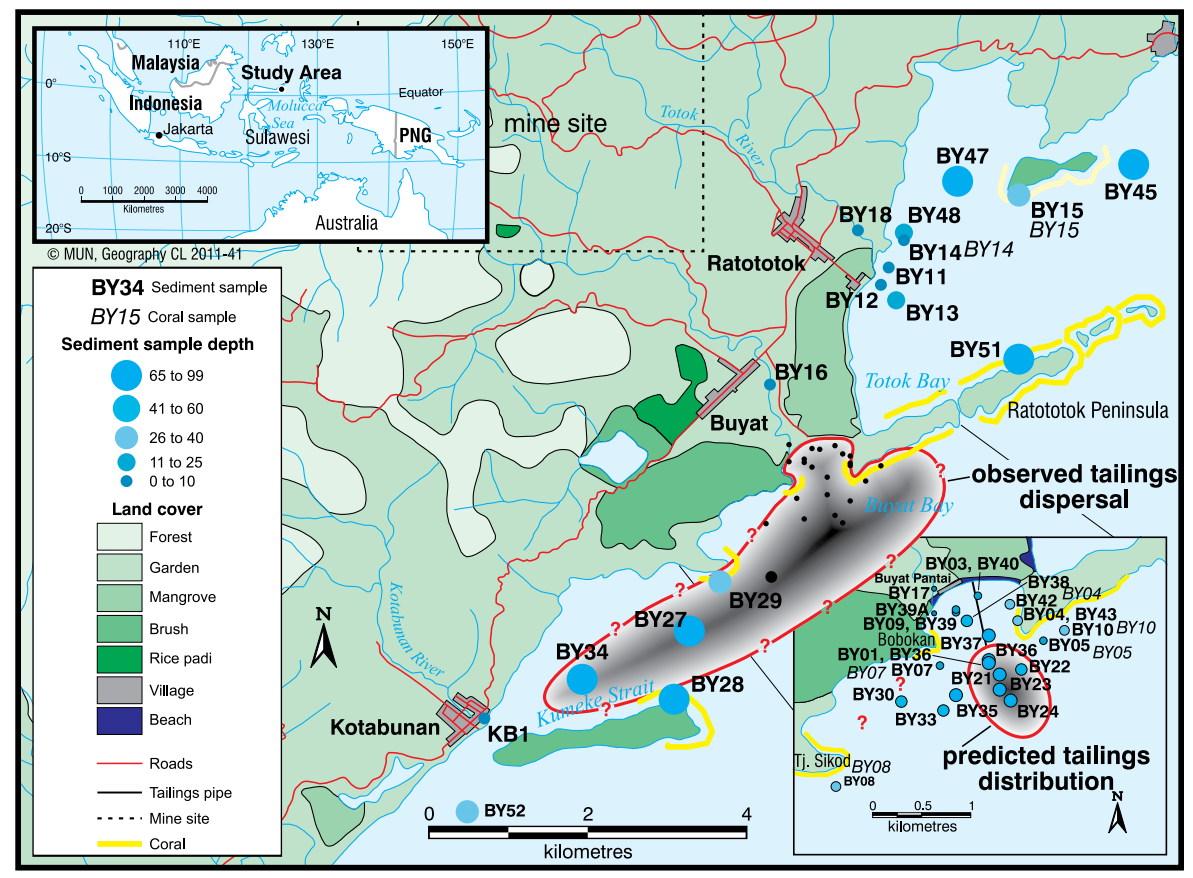

Tailings were identified visually by their pink to rusty brown color (Figure 4), and chemically by the relative abundance of different trace elements in the tailings, especially the very high ratio of $\mathrm{As}$ and $\mathrm{Sb}$ to lighter metals such as $\mathrm{Cr}, \mathrm{Cu}, \mathrm{Co}$, and $\mathrm{Ni}$, which were found in approximately equal concentrations in fluvially derived, reference, and premine sediments (Figure 5; Edinger et al., 2007). Tailings were found in fringing coral reef sediments in waters as shallow as $20 \mathrm{~m}$ (Edinger et al., 2007), and corals smothered in red fine-grained sediment resembling the tailings were observed in waters as shallow as $10 \mathrm{~m}$ (Figure 6; see video and figure at http://www.tos.org/oceanography/ archive/25-2_edinger.html\#supplement).

When whole sediments were sieved to the $<63 \mu \mathrm{m}$ fraction, arsenic

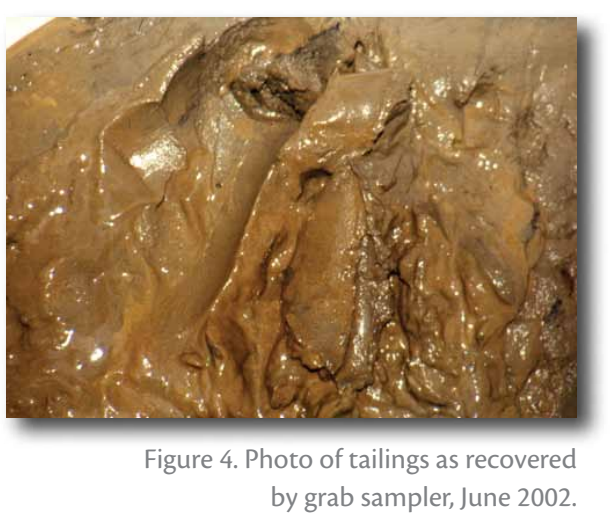

Figure 3. Detail map of sediment samples and coral reefs near Newmont Minahasa Raya gold mine, Indonesia. Inset map indicates tailings pipe and modeled distribution of tailings (PTNMR, 2002b), while the broader map shows observed dispersal of tailings. Question marks along the edge of the observed tailings dispersal area indicate a lack of observations seaward, eastward, and where sampling did not detect the edge of the tailings contaminated area. Modified from Edinger et al. (2008) 
concentrations in reef sediments at the fringing coral reef closest to the tailings outfall were $>250 \mathrm{ppm}, 15-20$ times higher than the pre-mining and uncontaminated reference samples, indicating that the tailings comprised up to $30 \%$ of the mud fraction of sediment at this site (Edinger et al., 2008). Antimony concentrations were consistently high in all the tailings-contaminated sediments, but relatively insoluble antimony oxides dominated antimony mineralogy in the tailings (Blackwood and Edinger, 2007). Despite the mining company assertion that tailings distributed throughout the bay in 1996 were subsequently buried by fluvial sediment, grab samples taken in 2002 and 2004 with a hand-held grab sampler with $15 \mathrm{~cm}$ scoops recovered surficial sediments bearing arsenic and

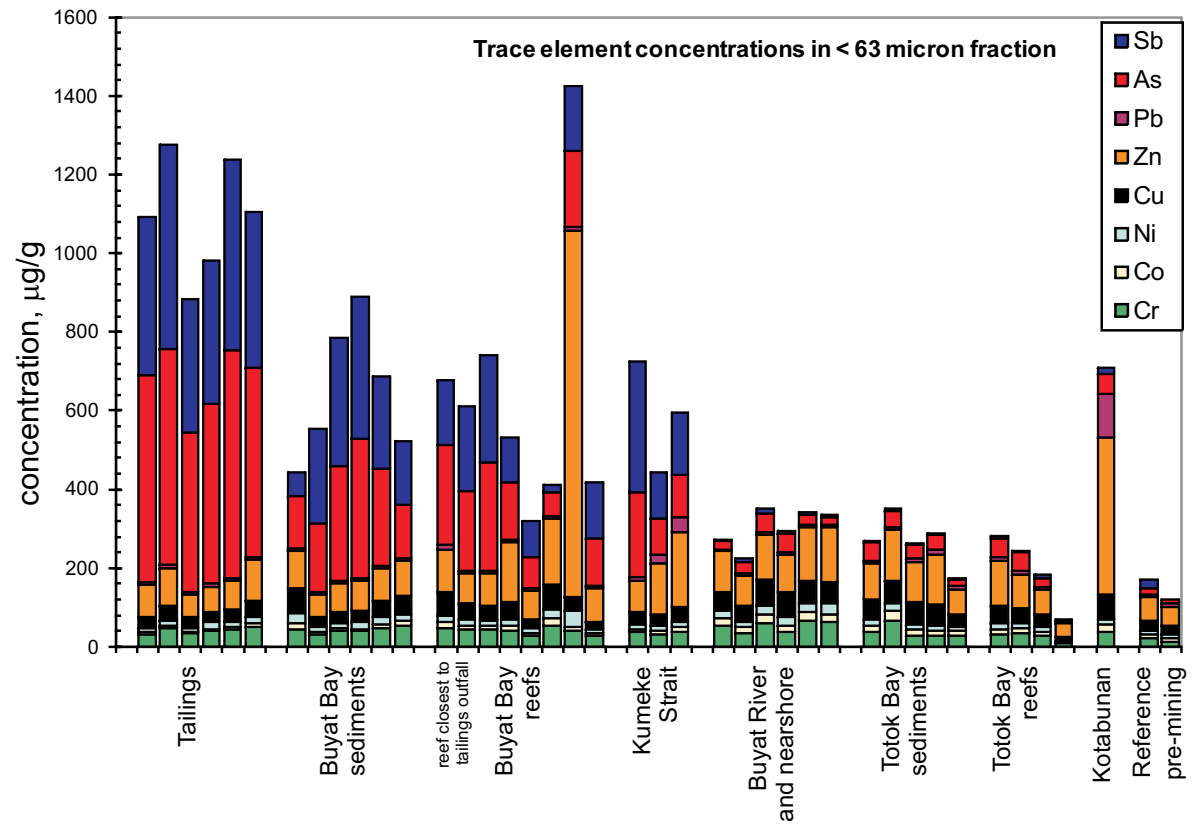

Figure 5. Trace element concentrations in sediment samples surrounding Newmont Minahasa Raya gold mine, Indonesia. STD affects Buyat Bay, while artisanal gold mining using mercury amalgamation affects Totok Bay and Kotabunan watersheds. Modified from Edinger et al. (2008) antimony concentrations, suggesting that $30-60 \%$ of the fine-grained fraction was composed of tailings (Figure 5). These high concentrations can be explained either by continued dispersal of tailings from the tailings pile to the shallower portions of the bay, or by bioturbative mixing of combined tailings and posttailings sediment. Although diagenesis could contribute to arsenic enrichment of surface sediments (e.g., Martin and Pedersen, 2002), such enrichment would seem unlikely for antimony, which was mostly present as highly insoluble antimony oxide. The relatively constant proportions of arsenic and antimony in the tailings-contaminated sediment allowed tracing of tailings dispersal, and strengthens estimates of the proportion of fine sediments composed of dispersed tailings based on the elevated concentrations of these elements.

Coral skeletons can record the history of metals pollution from mine tailings and other sources (David, 2003; ReicheltBrushett and McOrist, 2003). Live Porites coral skeletons from the reef closest to the tailings outfall contained higher concentrations of chromium, copper, cobalt, lead, arsenic, antimony, and thallium than corals from a reference reef.

\section{B}

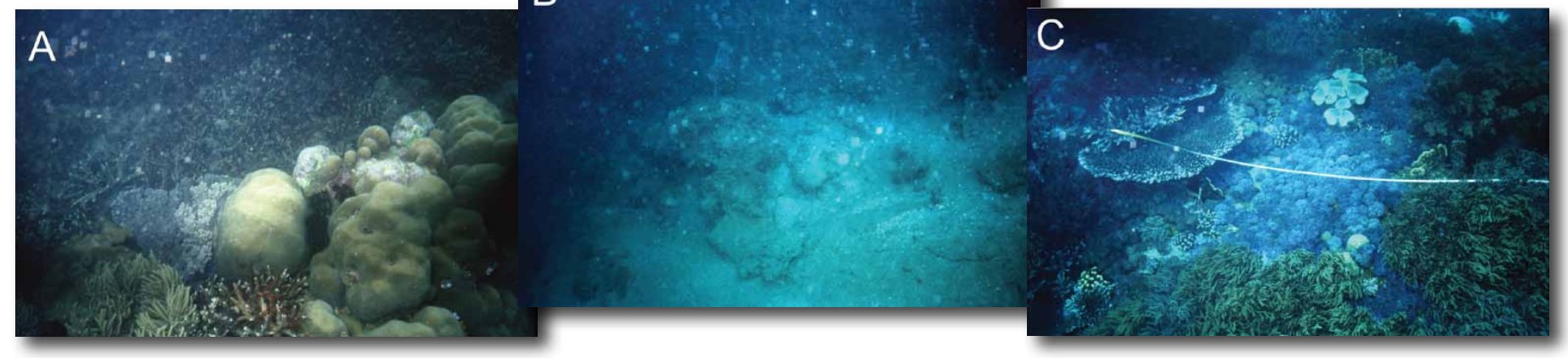

Figure 6. Photos of reefs in Buyat Bay area, June 2002. (A) Site BY04 (see Figure 2 for site locations), a reef closest to tailings outfall at $3 \mathrm{~m}$ depth. Note mixture of living and dead corals, and the high water turbidity, which is indicated by high scatter (vs. photo C). (B) Site BY04 is a reef closest to tailings outfall at $5 \mathrm{~m}$ depth. Note abundance of sediment on the seafloor, some of which is smothering corals. The sediment visually and chemically resembles tailings. (C) Site BY06 is a reef approximately $2 \mathrm{~km}$ seaward of tailings outfall, with no evidence of contamination. Note excellent water clarity, high live coral cover, and diversity. 
Ironically, the differences among reefs were statistically significant for most of the trace elements, but not for arsenic. Tailings-derived trace elements, particularly arsenic and antimony, were contained in the coral skeletons as microscopic particles of sediment, rather than as dissolved metals incorporated directly into the coral skeleton (Edinger et al., 2008). Arsenic is one of several miningderived toxic trace elements in which the size of the atom is incompatible with the aragonite crystal lattice that makes up the coral skeleton (Howard and Brown, 1984). The high within-sample variability in arsenic concentrations associated with the uneven distribution of sediment particles within the skeletons blurred the broader pattern, and explained the lack of statistical significance in differences in coral skeleton arsenic concentrations among reefs. Although dead corals were abundant on the reef closest to the tailings outfall, and many of the dead or dying corals appeared smothered by sediments the color of the tailings, we have no direct chemical evidence of the tailings' toxicity to the corals. Rather, the coral skeletons appeared to be passive recorders of the sediment contamination. Fishermen reported reef fish with tumors that were caught near both the reef closest to the tailings outfall and other reefs subjected to tailings dispersal.

The spatial distribution of tailingscontaminated sediment extended as far as $3.5 \mathrm{~km}$ from the end of pipe and over an area of at least $4.5 \mathrm{~km}^{2}$, and probably more. It is not possible to determine accurately the proportion of the total tailings volume that dispersed into shallow water because the total area affected by tailings dispersal is not known. A maximum dispersal distance can be determined shoreward and to the southwest, but seaward dispersal, and eastward dispersal along the Ratototok Peninsula (past station BY10; see

Figure 3 for location) were not sampled. Very crude estimates of total tailings dispersal were calculated based on the following assumptions, with contamination zones estimated from the degree to which arsenic and antimony concentrations were elevated above background, in conjunction with mining company estimates of tailings thickness away from the tailings pile (PTNMR, 2002a). Areas were estimated as the minimumsize polygon containing the sampling points within zones of high, medium, and low tailings contamination, measured in ArcMap 9.3. First, the volume of tailings in the tailings pile itself was measured as the volume of a cone of $0.285 \mathrm{~km}^{2}$ basal area and $11 \mathrm{~m}$ in height (PTNMR, 2002a). The volume of tailings dispersed to inner Buyat Bay was estimated as a $30 \mathrm{~cm}$ thick wedge of tailings in the $0.5 \mathrm{~km}^{2}$ highly contaminated zone of inner Buyat Bay, with the thickness estimate based on mining company core-based estimates of $20-40 \mathrm{~cm}$ thickness (PTNMR, 2002a). In the $\sim 2 \mathrm{~km}^{2}$ documented moderately contaminated dispersal zone immediately outside Buyat Bay, including reef samples BY05 and B10 (see Figure 3 for location), tailings depth was estimated to be one-third that of the inner bay, hence, a depth of $10 \mathrm{~cm}$, less than the mining company estimate of $15 \mathrm{~cm}$ tailings thickness to the south and west of the tailings pile (PTNMR, 2002a). Finally, for the remaining $2.5 \mathrm{~km}^{2}$ of the tailings dispersal area as far southwest as Kumeke Island, tailings depth was assumed to be $<10 \%$ of that in the inner bay, or $2.5 \mathrm{~cm}$.
These calculations suggest that approximately $70 \%$ of the tailings remained in the area of the modeled distribution, while about $30 \%$ of the tailings dispersed away from this zone. Confidence in these estimates of total dispersal is low, and the total volume of tailings dispersed away from the main pile is probably underestimated. Based on mining company discharge rates of $123.6 \mathrm{~m}^{3} \mathrm{hr}^{-1}$ at $50 \%$ water content, the volume change of the tailings pile between 1999 and 2000 was approximately $62 \%$ of the annual tailings solid volume discharge, without accounting for compaction. The difference in volume can probably be attributed to a combination of ongoing tailings dispersal and compaction of the tailings pile after initial dewatering. From the standpoint of the villagers, dispersal into the bay, and onto their fishing grounds within the bay and along the fringing coral reefs, was the most serious impact.

Despite the crude nature of these estimates of total dispersal, the dispersal data are sufficient to demonstrate that the observed dispersal area was more than 10 times greater than the predicted dispersal area based on the tailings modeling and mine closure studies (PTNMR, 2002a,b). Furthermore, according to the environmental impact assessment, the observed tailings dispersal should not have occurred at all. The causal link between tailings dispersal and the observed fish kills and fish tumors in areas of tailings dispersal reported by local fishermen has not been published in the scientific literature. Nonetheless, use of local ecological knowledge (LEK) in fisheries management, where compared with scientific survey data, has repeatedly demonstrated the validity of LEK (e.g., Gass and Willison, 2005). 
The mining company based its tailings distribution models on the assumption of a seasonally stable thermocline at $50 \mathrm{~m}$ depth, slightly above the depth of the tailings pile (PTNMR, 1994, 2002b), yet the CTD (conductivity-temperaturedepth) profile data included in the mine's environmental impact study (PTNMR, 1994) indicate high seasonal variability in thermocline depth and intensity, with thermocline depth ranging between 50 and $100 \mathrm{~m}$. A subsequent study based on CTD data collected in 1997, shortly after the mine opened and fishermen began reporting tailings dispersal, also showed high seasonal variability in thermocline depth and stability, with the thermocline as deep as $80 \mathrm{~m}$, and density stratification collapsing in July and August (Figure 7; Prisetiahadi and Yanaga, 2008). The oceanographic study recommended a minimum depth of the tailings pile at $135 \mathrm{~m}$, based on the seasonal variability in stratification. To reach this depth, the tailings pipeline would have had to be at least $5 \mathrm{~km}$ long. Furthermore, the environmental risk assessment for the mine identified possible internal waves propagating along the thermocline (Shepherd-Miller Inc., 2001). One possible explanation for how the tailings were dispersed is that internal waves propagating along the seasonally variable thermocline entrained the tailings, allowing dispersal by the internal waves, or by tidally induced currents. The fact that all the necessary oceanographic data to indicate seasonal variation in the thermocline depth had been collected before the STD operations commenced is important, because it shows that the mining company could have identified the risk of tailings dispersal based on the data available before they began dumping the tailings.

Ironically, company monitoring reports, the company's mine closure study (PTNMR, 2002b) and a Commonwealth Scientific and Industrial Research Organisation (CSIRO)

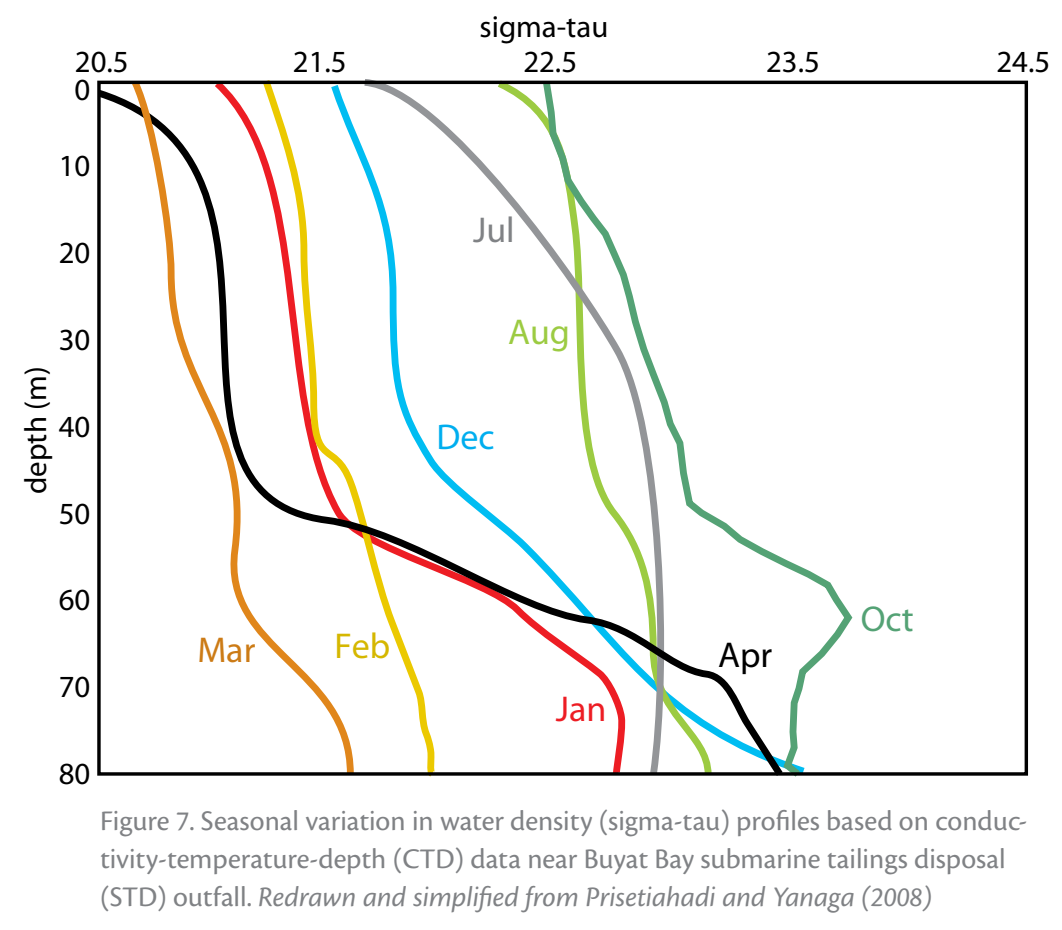


the mine identified arsenic and mercury as the major contaminants of concern, and tailings treatment was designed to reduce the solubility of these elements. Although antimony has since been recognized as a widespread contaminant of concern (Reimann et al., 2010; Wu et al., 2011), it was not considered important by the mining company at the time of the environmental impact assessment. Extraction of the gold required oxidative treatment based on roasting, followed by cyanidation and electro-winning. Whole ore was roasted at $550-580^{\circ} \mathrm{C}$ in the presence of limestone and dolomite from the host rock, in the hope of capturing some arsenic as magnesium arsenate. Tailings were treated with ferrous sulfate to produce two other arsenic-bearing phases, ferric arsenate and arsenical ferrihydrite (Weeks and Wan, 2000). These aspects of tailings treatment were intended to stabilize arsenic in the tailings, in order to minimize the risks of arsenic toxicity after tailings were deposited into nearby Buyat Bay.

The mine collected water samples a few meters above the tailings pile as part of its environmental monitoring program, and consistently reported low dissolved arsenic concentrations in the water above the tailings pile. Due to ongoing environmental concerns about the STD system, the mining company also installed sediment pore water samplers in four locations around the bay (PTNMR, 2002b). Near the base of the reef closest to the tailings outfall, the sediment pore water samplers found maximum concentrations of dissolved arsenic of 2,000 $\mu \mathrm{g} \mathrm{L}^{-1}$ about $20 \mathrm{~cm}$ below the sediment-water interface, and declining toward the sediment surface. This pattern of dissolved arsenic dissolution within sediment pore water matches predictions based on increased solubility of metastable arsenic phases under reducing conditions (Rochette et al., 1998; Zhang and Moore, 1997; Zhang et al., 2005). Ironically, dissolved arsenic concentrations at $20 \mathrm{~cm}$ sediment depth were higher in the tailings-contaminated sediments at the base of the reef than in the tailings themselves, where maximum pore water concentrations were $300 \mu \mathrm{g} \mathrm{L}{ }^{-1}$. This difference likely resulted from higher organic content in the tailings-contaminated sediment than in the tailings themselves, causing more strongly negative redox conditions, which promoted greater arsenic dissolution (Martin and Pedersen, 2002; Blackwood and Edinger, 2007) and methylation of arsenic that in turn increased its bioavailability. Alternatively, the difference in dissolved arsenic concentrations in the sediment pore water could be ascribed to the high sediment accumulation rate at the tailings outfall, such that the dissolved arsenic concentrations in sediment pore water at the tailings outfall increased continuously with depth in the sediment profile.

The distributions and concentrations of dissolved arsenic in sediment pore water matched the results of a sequential extraction study that found up to $30 \%$ of the arsenic within the tailings to be in weak-acid soluble phases, and a further $20 \%$ in metastable phases such as ferric arsenate and iron and manganese oxy-hydroxides (Blackwood and Edinger, 2007). For example, ferric arsenate and calcium arsenate, two of the tailings components that probably dissolved in the weak acid extraction, are relatively insoluble under aerobic conditions, but dissolve readily under reducing conditions (Rochette et al., 1998; Zhu et al., 2005). The concentration of labile (weak-acid soluble) arsenic in the tailings was more than four times greater than the probable effect level for total arsenic in marine sediments (41.6 mg kg-1; CCME, 2002), implying significant potential for arsenic toxicity in the mine tailings, both at the end of pipe and in reef and bay sediments into which the tailings were mixed as they dispersed. The sequential extraction study, combined with the sediment pore water profiles and the dispersal of the tailings onto reefs close to the tailings pipe, suggests that the STD system in Buyat Bay polluted the bay with geochemically unstable forms of arsenic (Blackwood and Edinger, 2007).

\section{Mercury Contamination at Newmont Minahasa Raya}

Mercury was one of the most contentious topics in the NMR example because of the widespread mercury contamination from artisanal gold mining of native gold deposits in volcanic rocks surrounding the refractory Carlin-like deposit. Concentrations of total mercury in marine sediments declined exponentially with distance from the mouth of the Totok River, in whose watershed artisanal mining is practiced (Edinger et al., 2007). Concentrations of total mercury and methyl mercury in estuarine and marine sediments were highest in Totok Bay (affected by artisanal gold mining), intermediate in Buyat Bay (the STD site), and lowest in Bajo, a reference site with a river draining a mapped but unexploited gold deposit in volcanic rocks (Lasut et al., 2010). The ratio of methyl mercury to total mercury was the same in all three locations, indicating that 
mercury from mine tailings, artisanal mining, and natural, undisturbed geologic sources all underwent methylation in equal proportions. In all three locations, methyl mercury accumulated in seaweed, invertebrates, and fishes, and methyl mercury concentrations in biota increased with trophic level. Analysis of human hair samples showed that adult
An additional source of mercury contamination from the NMR mine was the ore roasting, in which mercury was volatilized. Although the mine installed mercury scrubbers on the smokestacks from its roaster, they were not functional for most of the mine's lifespan, causing the mine to release 17-30 tonnes of mercury over the eight years of mine opera- biologically available, as observed with mercury methylation and incorporation into the food chain in Buyat Bay (Lasut et al., 2010). Furthermore, the shallow depth of the tailings outfall and seasonal thermocline variability in the NMR mine example resulted in dispersal of the tailings into shallow water and fringing reefs that were regularly used as fishing grounds by the local population. Dispersal of the geochemically unstable ore into shallow waters exploited as fishing grounds provided a potential pathway for arsenic and mercury contamination of the marine food web, including fish species consumed by local villagers. Had the mine wanted to extend the pipe to reach a depth $>100 \mathrm{~m}$ and slope $>12^{\circ}$, as recommended by STD proponents, the pipeline would have had to be $>5 \mathrm{~km}$ long, with the attendant increased risk of pipe bursts. Had the mine made a long pipe to reach deeper water, the dispersal onto local fringing reefs might have been avoided, but the inherent mineralogical and geochemical instability of the tailings would have remained a problem, just in a different place. Furthermore, there have been no studies of the deepwater (> $200 \mathrm{~m}$ ) invertebrate or fish faunas of the Buyat-Ratototok region, but diverse deepwater coral and fish faunas near North Sulawesi, including an Indonesian coelacanth species, indicate a potential for high biodiversity (Fricke et al., 2000). Thus, the NMR case study represents a poorly executed application of a tailings management technique that was also inappropriate for its ore type. The mining company argued for STD on the basis of the region's high rainfall and seismic activity, but did not perform a rigorous evaluation of terrestrial vs. marine tailings disposal options (PTNMR, 1994; 
Shepherd-Miller Inc., 2001).

In the other gold mines where STD has been applied or considered, the reported impacts are highly variable. The Lihir and Misima gold mines have both described some impacts on the surrounding environment from STD, including sedimentation (Rotmann and Thomas, in press) and metals uptake by corals (Fallon et al., 2002), and mercury and arsenic incorporation into fishes (Fry et al., 2006; Brewer et al., 2007; Shimmield et al., 2010). Relatively little has been published on the impacts of STD at the Batu Hijau porphyry coppergold deposit, whose tailings contain less than 3 ppm arsenic. An experimental study on meiofauna recolonization of the Batu Hijau tailings found normal shallow-water meiofauna within less than one year of deployment (Gwyther et al., 2009), although the interpretations of this study are not readily applicable to other mines, or to larger invertebrates. Copper sulfides in subaerially exposed stockpiled low-medium grade Batu Hijau ore were more unstable than those in unoxidized higher-grade tailings (Sahami et al., 2011).

Pre-mine experimental field or lab studies of possible STD for gold mines in Alaska and Greenland have found measurable impacts of variable and perhaps uncertain duration (Johnson et al., 1998a,b; Kline and Stekoll, 2001; Matthies et al., 2011). In the Kensington gold mine in Alaska, a carbonate-hosted vein gold deposit with low arsenic content tailings, STD and dry-stack tailings management options were rejected in favor of subaqueous tailings disposal in a natural lake, the level of which was raised by a dam (USFS, 2011). This subaqueous tailings disposal was only permitted after a controversial US Supreme Court decision that the tailings could be considered "fill" rather than toxic sediment. Preliminary testing of tailings from the nearby historical Alaska-Juneau gold mine, which was considered for re-opening in the 1990s, found that juvenile flatfish avoided the tailings (Johnson et al., 1998a), and that the tailings had the potential to impact spawning success and behavior of tanner crabs, a commercial fishery species (Johnson et al., 1998b). Preliminary analysis of geochemical stability of gold mine tailings from the Nalunaq mesothermal gold-vein native gold deposit in Greenland, in which native gold was associated with arsenopyrite in igneous rocks, also suggested arsenic mobility. A 20-week experimental lab study prior to potential STD indicated instability of cadmium and arsenic in the tailings under seawater (Matthies et al., 2011). The authors of that study recommended longer-term field testing to ensure stability of arsenic and cadmium before further consideration of plans for STD in this high-Arctic gold mine. The instability of arsenopyrite under the reducing conditions of a lab study (Matthies et al., 2011) and the inherent toxicity of arsenic and mercury, combined with the potential for tailings dispersal in unanticipated directions, suggest that STD is probably inappropriate for all arsenic-rich gold ores.

\section{ACKNOWLEDGEMENTS}

The field research reviewed here would have been impossible without the cooperation of the villagers of Buyat Pantai. Thanks are due to the co-authors of previous papers about Buyat Bay, to field assistants from Buyat
Pantai, nongovernmental organizations, and Universitas Sam Ratulangi in Manado, Indonesia, and to student lab assistants and technicians at Memorial University. G. Brunskill, T. Done, G. Layne, J. Rendell, B. Sherriff, and two anonymous reviewers provided helpful comments. Research was funded by grants from Memorial University and the Natural Sciences and Engineering Research Council of Canada (NSERC). This review was written while the author was on sabbatical leave at the Laboratoire de Géologie des Systèmes et Réservoirs Carbonatés, Université de Provence, in Marseille, France. The author thanks Université de Provence for support. Dedicated to the memory of Ida Halperin.

\section{REFERENCES}

Ahrens, M.J., and G.R. Lopez. 2001. In-vivo characterization of the gut chemistry of small deposit-feeding invertebrates. Pp. 349-368 in Organism-Sediment Interactions. J.Y. Aller, S.A. Woodin, and R.C. Aller, eds, Belle Baruch Institute for Marine Biology and Coastal Research, University of South Carolina Press.

Alpers, C.N., M.P. Hunerlach, J.T. May, and R.L. Hothem. 2005. Mercury contamination from historical gold mining in California. United States Geological Survey Fact Sheet 2005-3014, 6 pp. Available at http://pubs.usgs. gov/fs/2005/3014 (accessed February 13, 2012).

Andreae, M.O., and D. Klumpp. 1979. Biosynthesis and release of organoarsenic compounds by marine algae. Environmental Science and Technology 13:738-741, http://dx.doi. org/10.1021/es60154a001.

Apte, S.C., S.L. Simpson, R.F. Jung, G.E. Batley, and L.T. Hales. 2004. P.T. Newmont Minahasa Raya, Environmental Monitoring Study, August 2004. CSIRO Centre for Advanced Analytical Chemistry Report No. ET/IR729R, 82 pp.

Blackwood, G.M., and E.N. Edinger. 2007. Mineralogy and heavy metal speciation patterns of shallow marine sediments affected by submarine tailings disposal and artisanal gold mining, Buyat-Ratototok district, North Sulawesi, Indonesia. Environmental Geology 52:803-818, http://dx.doi.org/10.1007/s00254-006-0517-5. 
Bjørgesæter, A., and J.S. Gray. 2008. Setting sediment quality guidelines: A simple yet effective method. Marine Pollution Bulletin 57:221-235, http://dx.doi.org/10.1016/ j.marpolbul.2008.04.022.

Blanchette, M.C., T.P. Hynes, Y.T.J. Kwong, M.R. Anderson, G. Veinott, J.F. Payne, C. Stirling, and P.J. Sylvester. 2001. A chemical and ecotoxicological assessment of the impact of marine tailings disposal. Pp. 323-331 in Tailings and Mine Waste '01: Proceedings of the Eighth International Conference on Tailings and Mine Waste '01, Fort Collins, Colorado, USA, 16-19 January 2001. A.A. Balkema, Rotterdam.

Brewer, D.T., D.A. Milton, G.C. Fry, D.M. Dennis, D.S. Heales, and W.N. Venables. 2007. Impacts of gold mine waste disposal on deepwater fish in a pristine tropical marine system. Marine Pollution Bulletin 54:309-321, http://dx.doi.org/ 10.1016/j.marpolbul.2006.10.011.

Burd, B., R. Macdonald, and J. Boyd. 2000. Punctuated recovery of sediments and benthic infauna: A 19-year study of tailings deposition in a British Columbia fjord. Marine Environmental Research 49:145-175, http:// dx.doi.org/10.1016/S0141-1136(99)00058-6.

Burns, R.G., and V.M. Burns. 1979. Manganese oxides. Pp. 1-46 in Marine Minerals. R.G. Burns, ed., Mineralogical Society of America Short Course Notes, vol. 6, Mineralogical Society of America.

Churchill, R.C., C.E. Meathrel, and P.J. Suter. 2004. A retrospective assessment of gold mining in the Reedy Creek sub-catchment, northeast Victoria, Australia: Residual mercury contamination 100 years later. Environmental Pollution 132:355-363, http://dx.doi.org/ 10.1016/j.envpol.2004.03.001.

CCME (Canadian Council of Ministers of Environment). 2002. Canadian sediment quality guidelines for the protection of aquatic life. Summary tables. Updated in: Canadian Environmental Quality Guidelines. Publication No. 1299, Canadian Council of Ministers of the Environment, Winnipeg, MB, Canada.

David, C.P. 2002. Heavy metal concentrations in marine sediments impacted by a minetailings spill, Marinduque Island, Philippines. Environmental Geology 42:955-965, http:// dx.doi.org/10.1007/s00254-002-0601-4.

David, C.P. 2003. Heavy metal concentrations in growth bands of corals: A record of mine tailings input through time (Marinduque Island, Philippines). Marine Pollution Bulletin 46:187-196, http://dx.doi.org/10.1016/ S0025-326X(02)00315-6.

de Lacerda, L.D. 2003. Updating global Hg emissions from small-scale gold mining and assessing its environmental impacts. Environmental Geology 43:308-314, http://dx.doi.org/10.1007/ s00254-002-0627-7. de Lacerda, L.D., and W. Salomons. 1998. Mercury From Gold and Silver Mining: A Chemical Time $B o m b$ ? Springer, Berlin Heidelberg New York, 146 pp.

De Leo, F.C., C.R. Smith, A.A. Rowden, D.A. Bowden, and M.R. Clark. 2010. Submarine canyons: Hotspots of benthic biomass and productivity in the deep sea. Proceedings of the Royal Society of London B 277:2,783-2,792, http://dx.doi.org/10.1098/rspb.2010.0462.

Donato, D.B., O. Nichols, H. Possingham, M. Moore, P.F. Ricci, and B.N. Noller. 2007. A critical review of the effects of gold cyanide-bearing tailings solutions on wildlife. Environment International 33:974-984, http:// dx.doi.org/10.1016/j.envint.2007.04.007.

Edinger, E.N. 2008. Environmental impacts of nickel mining: Four case studies, three continents, and two centuries. Pp. 103-124 in Mining Town Crisis: Globalization, Labour, and Resistance in Sudbury. D. Leadbeater, ed., Fernwood Books, Halifax, Canada.

Edinger, E.N., K. Azmy, W. Diegor, and P.R. Siregar. 2008. Heavy metal contamination from gold mining recorded in Porites lobata skeletons, Buyat-Ratototok district, North Sulawesi, Indonesia. Marine Pollution Bulletin 56:1,553-1,569, http:// dx.doi.org/10.1016/j.marpolbul.2008.05.028.

Edinger, E.N., P.R. Siregar, and G.M. Blackwood. 2007. Heavy metal concentrations in shallow marine sediments affected by submarine tailings disposal and artisanal gold mining, BuyatRatototok district, North Sulawesi, Indonesia. Environmental Geology 52:701-714, http:// dx.doi.org/10.1007/s00254-006-0506-8.

Eisler, R. 2004a. Biogeochemical, Health, and Ecotoxicological Perspectives on Gold and Gold Mining. CRC press, 376 pp.

Eisler, R. 2004b. Arsenic hazards from gold mining to humans, plants, and animals. Reviews of Environmental Contamination and Toxicology 180:130-165, http://dx.doi. org/10.1007/0-387-21729-0_3.

Eisler, R. 2004c. Mercury hazards from gold mining to humans, plants, and animals. Reviews of Environmental Contamination and Toxicology 181:139-198, http:// dx.doi.org/10.1007/0-387-21733-9_4.

Ellis, D.V., G.W. Poling, and R.L. Baer. 1995. Submarine tailings disposal (STD) for mines: An introduction. Marine Georesources and Geotechnology 13:3-18, http://dx.doi.org/ 10.1080/10641199509388275.

Ellis, D.V. 2008. The role of deep submarine tailings placement (STP) in the mitigation of marine pollution for coastal and island mines. Pp. 23-51 in Marine Pollution: New Research. T.N. Hofer, ed., Nova Science Publishers.

Fallon, S.J., J.C. White, and M.T. McCulloch. 2002. Porites corals as recorders of mining and environmental impacts: Misima Island, Papua
New Guinea. Geochimica et Cosmochimica Acta 66:45-62, http://dx.doi.org/10.1016/ S0016-7037(01)00715-3.

Fricke, H., K. Hissmann, J. Schauer, M. Erdmann, M.K. Moosa, and R. Plante. 2000. Conservation: Biogeography of the Indonesian coelacanths. Nature 403:38, http://dx.doi.org/10.1038/47400.

Fry, G.C., D.T. Brewer, and W.N. Venables. 2006. Vulnerability of deepwater demersal fishes to commercial fishing: Evidence from a study around a tropical seamount in Papua New Guinea. Fisheries Research 81:126-141, http:// dx.doi.org/10.1016/j.fishres.2006.08.002.

Gass, S.E., and J.H.M. Willison. 2005. An assessment of the distribution of deep-sea corals in Atlantic Canada by using both scientific and local forms of knowledge. Pp. 223-245 in Coldwater Corals and Ecosystems. A. Freiwald and J.M. Roberts, eds, Springer-Verlag, Heidelberg.

Howard, L.S., and B.E. Brown. 1984. Heavy metals and reef corals. Oceanography and Marine Biology Annual Review 22:195-210.

Gwyther, D., G.H, Batterham, J. Waworuntu, T. Gultom, W. Prayogo, Susetiono, and Karman. 2009. Recolonisation of mine tailing by meiofauna in mesocosm and microcosm experiments. Marine Pollution Bulletin 58:841-850, http://dx.doi.org/10.1016/ j.marpolbul.2009.01.019.

Jambor, J.L. 2003. Mine-waste mineralogy and mineralogical perspectives of acid-base accounting. Pp. 117-146 in Mineralogical Association of Canada Short Course Notes, vol. 31.

Jamieson, H.E. 2011. Geochemistry and mineralogy of solid mine waste: Essential knowledge for predicting environmental impact. Elements 7:381-386, http://dx.doi.org/10.2113/ gselements.7.6.381.

Jeffery, J. 1988. Behaviour of trace metals in a tropical river system affected by mining. Pp. 259-274 in Chemistry and Biology of Solid Waste: Dredged Material and Mine Tailings. N. Marshman and W. Salomons, eds, SpringerVerlag, Berlin.

Jewett, S.C., H.M. Feder, and A. Blanchard. 1999. Assessment of the benthic environment following offshore placer gold mining in the northeastern Bering Sea. Marine Environmental Research 48:91-122, http://dx.doi.org/10.1016/ S0141-1136(99)00034-3.

Johnson, S.W., S.D. Rice, and D.A. Moles. 1998a. Effects of submarine mine tailings disposal on juvenile yellowfin sole (Pleuronectes asper): A laboratory study. Marine Pollution Bulletin 36:278-287, http://dx.doi.org/10.1016/ S0025-326X(97)00181-1.

Johnson, S.W., R.P. Stone, and D.C. Love. 1998b. Avoidance behavior of ovigerous Tanner crabs Chionoecetes bairdi exposed to mine tailings: A laboratory study. Alaska Fishery Research Bulletin 5:39-45. 
Kline, E.R., and M.S. Stekoll. 2001. Colonization of mine tailings by marine invertebrates. Marine Environmental Research 51:301-325, http:// dx.doi.org/10.1016/S0141-1136(00)00105-7.

Lalamentik, L.T.X. 2000. Coral Reef Conditions Around the Gold Mining Area of PT Newmont Minahasa Raya. Report from Faculty of Fisheries and Marine Science, Sam Ratulangi University, Manado, $37 \mathrm{pp}$.

Lasut, M.T., Y. Yasuda, E.N. Edinger, and J.M. Pangemanan. 2010. Distribution and accumulation of mercury derived from gold mining in marine environment and its impact on residents of Buyat Bay, North Sulawesi, Indonesia. Water, Air and Soil Pollution 208:153-164, http://dx.doi.org/10.1007/s11270-009-0155-0.

Magalhães, M.C.F. 2002. Arsenic: An environmental problem limited by solubility. Pure and Applied Chemistry 74:1,843-1,850, http://dx.doi. org/10.1002/chin.200313209.

Martin, A.J., and T.F. Pedersen. 2002. Seasonal and interannual mobility of arsenic in a lake impacted by metal mining. Environmental Science and Technology 36:1,516-1,523, http:// dx.doi.org/10.1021/es0108537.

Matthies, R., R.J. Bowell, and K.P. Williams. 2011. Geochemical assessment of gold mine tailings proposed for marine tailings disposal. Geochemistry: Exploration, Environment, Analysis 11:41-50, http://dx.doi. org/10.1144/1467-7873/09-016.

Mudd, G.M., and D.V. Boger. In press. Land-based tailings management: A viable alternative to marine tailings disposal. Oceanography.

Needham, S.J., R.H. Worden, and D. McIlroy. 2004. Animal-sediment interactions: The effect of ingestion and excretion by worms on mineralogy. Biogeosciences 1:113-121, http://www. biogeosciences.net/1/113/2004/bg-1-113-2004print.html.

Pauly, D., R. Watson, and J. Alder. 2005. Global trends in world fisheries: Impacts on marine ecosystems and food security. Philosophical Transactions of the Royal Society of London B 360:5-12, http://dx.doi.org/10.1098/ rstb.2004.1574.

Pedersen, T.F. 2001. Shouldn't we be putting our sulphide-rich mine tailings in the oceans or in lakes rather than on land? Pp 151-162 in Waters in Peril. L. Bendell-Young and P. Gallaugher, eds, Kluwer, Dordrecht.

Prisetiahadi, K., and T. Yanaga. 2008. Seasonal variation in the behavior of tailing wastes in Buyat Bay, Indonesia. Marine Pollution Bulletin 57:170-181, http://dx.doi.org/10.1016/ j.marpolbul.2007.10.034.

PTNMR (PT Newmont Minahasa Raya). 1994. Studi analisis dampak lingkungan kegiatan pertambangan emas di Minahasa dan Bolaang Mongondow, Sulawesi Utara, Indonesia. [Environmental Impact Assessment: Proposed
Minahasa Gold Project, Minahasa and Bolaang Mongondow, North Sulawesi, Indonesia]. PT Newmont Minahasa Raya, Jakarta, 487 pp. PTNMR. 2002a. Minahasa Mine Closure Plan. PT Newmont Minahasa Raya, Manado, 241. PTNMR. 2002b. Minahasa Gold Mine PostClosure Submarine Tailings Modeling Study. PT Newmont Minahasa Raya, Manado, 31 pp.

Reichelt-Brushett, A., and G. McOrist. 2003. Trace metals in the living and non-living components of scleractinian corals. Marine Pollution Bulletin 46:1,573-1,582, http://dx.doi. org/10.1016/S0025-326X(03)00323-0.

Reichelt-Brushett, A. In press. Risk assessment and ecotoxicology: Limitations and recommendations in the case of ocean disposal of mine waste in the coral triangle. Oceanography.

Reimann, C., J. Matschullat, M. Birke, and R. Salminen. 2010. Antimony in the environment: Lessons from geochemical mapping. Applied Geochemistry 25:175-198, http://dx.doi. org/10.1016/j.apgeochem.2009.11.011.

Renaut, R.W., and E.H. Gierlowski-Kordesch. 2010. Lakes. Pp. 541-576 in Facies Models 4. N.P. James and R.W. Dalrymple, eds, GeoText 6, Geological Association of Canada.

Rochette, E.A., G.C. Li, and S.E. Fendorf. 1998. Stability of arsenate minerals in soil under biotically generated reducing conditions. Soil Science Society of America Journal 62:1,530-1,537, http://dx.doi.org/10.2136/sssaj1998.036159950 06200060008x.

Rotmann, S., and S. Thomas. In press. Coral tissue thickness as a bio-indicator of mine-related turbidity stress on coral reefs at Lihir Island, Papua New Guinea. Oceanography.

Sahami, A., J. Waworuntu, and S. Fawcett. 2011. Geochemical reactivity of submarine tailings from the Batu Hijau mine. Mineralogical Magazine 75:1,777, http:// www.goldschmidt2011.org/abstracts/ abstractView? abstractId $=3725$.

Shaw, S.A., T.A. Al, and K.T.B. MacQuarrie. 2006. Mercury mobility in unsaturated gold mine tailings, Murray Brook mine, New Brunswick, Canada. Applied Geochemistry 21:1,986-1,998, http://dx.doi. org/10.1016/j.apgeochem.2006.08.009.

Shepherd-Miller Inc. 2001. Minahasa Marine Ecological Risk Assessment. Contract report prepared for PT Newmont Minahasa Raya, January 2001, 327 pp.

Shimmield, T.M., K.D. Black, J.A. Howe, D.J. Hughes, and T. Sherwin. 2010. Final Report: Independent Evaluation of Deep-Sea Mine Tailings Placement (DSTP) in PNG. Project Number 8.ACP.PNG.18-B/15. Scottish Association for Marine Science (SAMS), 293 pp.
Sink, K.J., W. Boshoff, T. Samaai, P.G. Timm, and S.E. Kerwath. 2006. Observations of the habitats and biodiversity of the submarine canyons at Sodwana Bay. South African Journal of Science 102:466-472.

Siregar, P.R. 2005. People need decent settlement. Opinion, Jakarta Post, November 29, 2005.

Turner, S.J., P.A. Flindell, D. Hendri, I. Hardjana, P.F. Lauricella, R.P. Lindsay, B. Marpaung, and G.P. White. 1994. Sediment-hosted gold mineralisation in the Ratatotok District, North Sulawesi, Indonesia. Journal of Geochemical Exploration 50:317-336, http://dx.doi. org/10.1016/0375-6742(94)90029-9.

USFS (US Forest Service). 2011. Kensington Mine. US Forest Service Alaska Region Briefing Paper, 1 p. Available online at: http://www.fs.usda.gov/ Internet/FSE_DOCUMENTS/stelprdb5299805. pdf (accessed February 14, 2012).

Walker, S.R., M.B. Parsons, H.E. Jamieson, and A. Lanzirotti. 2009. Arsenic mineralogy of near-surface tailings and soils: Influences on arsenic mobility and bioaccessibility in the Nova Scotia gold mining districts. Canadian Mineralogist 47:533-556, http://dx.doi.org/ 10.3749/canmin.47.3.533.

Weeks, T., and R.Y. Wan. 2000. Behavior of arsenic in refractory gold ore processing: A case study of PT Newmont Minahasa Raya. Pp. 125-133 in Minor Elements 2000. C.A. Young, ed., Society of Mineral and Metals Exploration, Littleton, CO.

Wu, F., A. Fu, B. Liu, C. Mo, B. Chen, W. Corns, and H. Liao. 2011. Health risk associated with dietary co-exposure to high levels of antimony and arsenic in the world's largest antimony mine area. Science of The Total Environment 409(18):3,344-3,351, http:// dx.doi.org/10.1016/j.scitotenv.2011.05.033.

Zhang, S., W. Li, X.-Q. Shan, A. Lu, and P. Zhou. 2005. Effects of low molecular weight organic anions on the release of arsenite and arsenate from a contaminated soil. Water Air, \& Soil Pollution 167:111-122, http:// dx.doi.org/10.1007/s11270-005-8219-2.

Zhang, Y., and J.N. Moore. 1997. Interaction of selenate with a wetland sediment. Applied Geochemistry 2:685-691, http://dx.doi.org/ 10.1016/S0883-2927(97)00025-5.

Zhu, Y.N., X.H. Zhang, Q.L. Xie, D.Q. Want, and G.W. Cheng. 2005. Solubility and stability of calcium arsenates at $25^{\circ} \mathrm{C}$. Water Air and Soil Pollution 169:221-238, http:// dx.doi.org/10.1007/s11270-006-2099-y. 